\title{
Chemical and Thermal Characterizations of Pinus sylvestris and Pinus pinaster
}

\author{
Gulnur Mertoglu Elmas and Nural Yilgor * \\ Chemical and thermal aspects of Pinus sylvestris and Pinus pinaster were \\ characterized, with consideration of non-extracted and cylohexane- \\ ethanol (EtOH)-extracted woods, holocellulose, and a-cellulose. The \\ chemical properties including cylohexane-EtOH solubility of wood were \\ determined by standard test methods, holocellulose, a-cellulose, lignin, \\ and ash components. Fourier transform infrared-attenuated total \\ reflection spectroscopic (FTIR-ATR) analysis revealed changes in the \\ chemical structure of the specimens. Lignin peaks were still observed in \\ holocelluloses' spectra, and substantial loss of polysaccharides were also \\ detected. Moreover, the $\alpha$-cellulose spectra of both softwoods included \\ bands belonging to polyoses. Pinus pinaster's holocellulose, a-cellulose, \\ and ash contents were higher than those of Pinus sylvestris but lignin and \\ cylohexane-EtOH-solubility amounts were lower. The mass loss during \\ degradation stage of Pinus sylvestris and Pinus pinaster was observed in \\ the extracted wood respectively as 73.0 and $74.5 \%$ within the 188.7 to \\ $422.9{ }^{\circ} \mathrm{C}$ range. The highest mass loss for Pinus sylvestris and Pinus \\ pinaster in the carbonization step was formed in their holocelluloses \\ respectively as 22.9 and $22.5 \%$ from $426^{\circ} \mathrm{C}$ to $1017{ }^{\circ} \mathrm{C}$.
}

Keywords: Pinus sylvestris; Pinus pinaster; Holocellulose; Alphacellulose; FTIR-ATR; TGA

Contact information: Department of Forest Industry Engineering, Forest Products Chemistry and Technology, Istanbul University-Cerrahpaşa, 34473, Turkey;

* Corresponding author: mertoglug@istanbul.edu.tr

\section{INTRODUCTION}

Wood is a natural material composed of many macromolecular polymeric structures including lignin and holocellulose (cellulose and polyoses). Wood also contains low-molecular-weight organic matter and inorganic substances (Fengel and Wegener 1989). Cellulose is a linear polymer composed of monomeric glucose units with $\beta$-D-1,4 glycosidic linkages consisting of amorphous and crystalline regions, where the crystalline structure provides its resistance to acidic and alkaline threats (Fengel and Wegener 1989; Gullichens 2000). Hemicellulose, which is a heterogeneous and branched low molecular polymer, is the second most abundant biopolymer present in wood after cellulose. It consists of different sugar units, such as glucose, mannose, galactose, xylose, and arabinose, linked by various bonds (Rowell 1983; Fengel and Wegener 1989; Esteves and Pereire 2009).

Pinus sylvestris is one of the most widely grown natural pine species in the world, found in almost all of northern Eurasia. It has been grown in Turkey at a height of $2700 \mathrm{~m}$ at the northern end of the forest boundary, and under different conditions in a wide variety of horizontal and vertical altitudes, up to the $70^{\text {th }}$ latitude. Pinus sylvestris is a domestic 
pine species most frequently used in industries. Pinus pinaster is an exotic coniferous species commonly used in coastal afforestation in Turkey (Akkemik 2018).

The industry pertaining to and the market for wood products and by-products as a lignocellulosic material is gaining importance. Wood is valuable in areas of manufacturing and industries such as the production of fiberboard, pulp and paper, and wood-polymer composites. Wood composite materials are used in a wide range of applications. The chemical and thermal characteristics of the raw wood determine the properties of the final wood products. Besides many valuable characteristics as a natural material, its renewability, sustainability, and recycling feature have brought an added value to the wood in recent decades.

The aim of this study was to determine the chemical compositions and analyze the thermal decompositions of Pinus sylvestris and Pinus pinaster softwood species, with consideration of their location of growth. These characteristics are important indicators of the technological characteristics of the raw material used for its product in the forest industry and fiber production. In contrast, many wood products can be recovered for reuse or recycling. Thus, knowing its chemical and thermal characteristics provides more reliability as an industry material. It is also important to explore the characteristics of wood delignification process with the help of instrumental methods and also learn more about thermal characteristics. In this work the removal of lignin and then also polyoses was monitored by means of IR spectra. Changes were revealed by comparing the sound wood samples. Wood flour and its components, such as non-extracted wood, extracted wood, holocellulose, and $\alpha$-cellulose are used are used as loader, support, and filling additives in polymer combinations. Their thermal degradation profiles can help to clarify the degradation pathways and to identify the additive component.

\section{EXPERIMENTAL}

\section{Material}

From Bursa, Turkey Pinus sylvestris (Scots pine; hereafter referred to as PS) and Pinus pinaster (Maritime pine; PP) were obtained from the Istanbul Forest District Directorate (Istanbul, Turkey). Two trees from each species were selected according to specimens of wood for chemical analysis according to TAPPI $257 \mathrm{~cm} \mathrm{85(2012)} \mathrm{"sampling}$ and preparing wood analysis." Three sample discs were taken from each tree, with $20 \mathrm{~cm}$ thickness. The barks were first removed when the wood samples were prepared.

\section{Methods}

Chemical tests

Disc samples were chipped to a thickness of $2 \mathrm{~mm}$ to $5 \mathrm{~mm}$ and ground in a Wiley laboratory mill (Philadelphia, PA, USA) according to the TAPPI T257-14 (2012) standard, and the wood flour was thus obtained. It was then screened using a shaking sieve, and the powders were collected that passed through a 40-mesh screen and stayed on the 100-mesh screen. The two milled specimens were used in parallel for each test experiment. The specimens were repeated according to each test standard by controlling the confidence level in the repeatability range. The moisture content was determined using TAPPI T258 om-94 (1994). The following measurements were also taken: ash content (TAPPI T211 om-12 (2012)); alcohol solubility (TAPPI T204 cm-07 (2007)); holocellulose content 
(Wise and John 1952); $\alpha$-cellulose (TAPPI T203 cm-09, 2009); and lignin content (Runkel and Wilke 1951).

\section{Thermogravimetric analysis (TGA)}

The wood flour specimens prepared were used to study the thermal decomposition via thermogravimetric analysis. The TG/TGA (thermogravimetry or thermogravimetric analysis) and DTG (derivative thermogravimetry) data were obtained on a TG/DTA (Model TG/DTA 6300; Seiko Instruments Inc., Friedberg, Germany). The analysis conditions involved heating at $10{ }^{\circ} \mathrm{C} / \mathrm{min}$ for wood flour and extracted wood flour, and at $5{ }^{\circ} \mathrm{C} / \mathrm{min}$ for holocellulose and alphacellulose, in an inert atmosphere of $\mathrm{N}_{2}$ gas under three bars of pressure at a constant flow rate of $100 \mathrm{~mL} / \mathrm{min}$. The specimens ( $5 \mathrm{mg}$ to $10 \mathrm{mg}$ ) were weighed in standard alumina crucibles and were heated from $20{ }^{\circ} \mathrm{C}$ to $1000{ }^{\circ} \mathrm{C}$ at a rate of $5^{\circ} \mathrm{C} / \mathrm{min}$ and $10{ }^{\circ} \mathrm{C} / \mathrm{min}$.

\section{Fourier transform infrared (FTIR) Analysis}

Fourier transform infrared absorption data were obtained using a FTIR spectrometer (PerkinElmer 100 FTIR spectrometer; PerkinElmer Inc., Bridgeport, CT, USA) combined with an attenuated total reflection (ATR) unit (The Universal ATR Accessory (UATR-PerkinElmer Exclusive); Bridgeport, CT, USA)) with a resolution of 4 $\mathrm{cm}^{-1}$ for 32 scans in a spectral range of $600 \mathrm{~cm}^{-1}$ to $4000 \mathrm{~cm}^{-1}$. Specimens were milled and passed through an 80-mesh sieve, and the analyses were performed on extracted wood, holocellulose, and alphacellulose specimens. The spectra were baseline corrected and normalized to the highest peak. The FTIR spectroscopy was improved using an ATR unit that provided direct interaction of the measuring beam with the sample and reflection of the attenuated radiation to the spectrometer, and increased the sensitivity of FTIR-based analyses.

\section{RESULTS AND DISCUSSION}

\section{Compositional Analysis}

The mechanical and strength properties of the fibers are primarily influenced by their chemical composition, which is mainly the contents of cellulose, hemicellulose, and lignin (Faruk et al. 2012; Poletto et al. 2014). The composition and contents of the cell wall components, such as alphacellulose, hemicellulose obtained by the application of diglyme method (Alves et al. 2018), and lignin, directly affect the mechanical and strength properties of the fibers (Satyanarayana et al. 2007; Cobas et al. 2013; Poletto et al. 2014). The results of the chemical analyses of PS and PP are shown in Table 1.

The contents of chemical compounds for PS and PP in Table 1, such as holocellulose, alphacellulose, lignin, cyclohexane-EtOH (ethyl alcohol)-extracted wood, and ash. While PS 's holocellulose and alphacellulose contents were higher than those of $\mathrm{PP}$, the lignin, cyclohexzane-EtOH-extracted wood, and ash contents were lower. As shown in Table 1, when the chemical components of PS and PP woods were compared, it was found that the amounts of holocellulose and alphacellulose in the PS wood increased $7.6 \%$ and $5.7 \%$, respectively, but the lignin, cyclohexane-EtOH-solubility, and ash amount decreased $3.7 \%, 50.6 \%$, and $26.3 \%$, respectively (Table 1).

The amounts of chemical components, specimens identification and location of the PP and PS are presented in Table 1. The chemical structure of PS in the location of Turkey 
when was compared with previous studies. It was found their rates such as holocellulose, alphacellulose, and lignin, cyclohexane-EtOH-solubility and ash the changes of 71.4$73.7 \%$; 48.6-68.2\%; 27.6-29.4\%; 5.8-6.7\% and 0.33-0.48\% respectively (Tables 1 and 2).

Table 1. Amounts of Chemical Compounds in the Softwoods

\begin{tabular}{|l|l|l|l|l|l|}
\hline Sample & $\begin{array}{l}\text { Holo-C } \\
\%\end{array}$ & $\begin{array}{l}\text { Alpha-C } \\
\%\end{array}$ & Lignin & $\begin{array}{l}\text { Alcl- } \\
\text { ben\% }\end{array}$ & $\begin{array}{l}\text { Ash } \\
\%\end{array}$ \\
\hline PP; Determined & 79.5 & 53.2 & 28.3 & 3.87 & 0.38 \\
\hline PS; Determined & 73.5 & 50.2 & 29.4 & 5.83 & 0.48 \\
\hline PS Bartın, Turkey (Kilic et al. 2010) & 73.7 & 68.2 & 28.6 & 6.71 & 0.45 \\
\hline PS;Kahramanmaraş (Tutus et al. 2010) & 71.4 & 48.6 & 27.6 & - & 0.33 \\
\hline PP; İmit Turkey (Gurboy 2000) & $82.0-80.6$ & $49.8-48.5$ & $27.2-27.4$ & $1.36-1.48$ & $0.35-0.33$ \\
\hline PP;Keşan, Turkey (Gurboy 2000) & $82.2-72.1$ & $49.8-47.8$ & $26.8-26.4$ & $2.47-2.08$ & $0.35-0.31$ \\
\hline PS; Fengel and Wegener 1989 & 74.3 & 52.2 C. & 26.3 & - & - \\
\hline PS; Wang and Wu 2016 & 73.5 & 47.8 & 23.5 & - & 0.21 \\
\hline
\end{tabular}

org.: orgininated; Alcl-ben\%: Alcohol-benzen\%; C:Cellulose; reg:region

The differences are likely to be caused by climatic and ecological environmental conditions. It was found that the chemical structural components of determined PS belonging to the Bursa region is similar to the chemical structural components of PS of Bartin location. Chemical components of PP that were compared in the location of Turkey exhibited ranges of holocellulose ( 72.1 to $82.2 \%$ ); alphacellulose (47.7 to $53.2 \%$ ), lignin (26.4 to $28.3 \%$ ), cyclohexane-EtOH-solubility (1.36 to $3.87 \%$ ); and ash (0.31 to $0.38 \%$ ), respectively. Fengel and Wegener (1989), and Wang and $\mathrm{Wu}$ (2016) reported similar findings for Pinus sylvestris for holocellulose $(74.3 \%, 73.5 \%)$ alphacellulose $(52.2 \%$, $53.2 \%)$, and lignin $(26.3 \%, 23.46 \%)$, respectively.

\section{FTIR Analysis}

The process of delignification and obtaining alphacellulose were monitored in the two different softwoods using FTIR, which is a useful technique for observing the changes in the chemical structure of wood. The FTIR spectra of PP and PS samples are shown in Figs. 1 and 2. The identification and explanations of the IR peaks are presented in Table 2. The peaks are defined with reference to literature reports (Harrington et al. 1964; Faix 1991; Pandey 1999; Schwanninger et al. 2004). There are some differences in the bands of spectra observed in this study compared to reports in the literature.

As is known, the aim of delignification is to remove lignin while preserving the wood carbohydrates. A truly successful delignification should remove all of lignin without significant dissolution and decomposition or modification of cellulose and polyoses. But during an acidified sodium chlorite delignification process some of the polysaccharides become soluble and the obtained holocellulose samples always result in losses of carbohydrates, especially low molecular weight polyoses (Fengel and Wegener 1984; Yilgor 2005). On the other hand, it is very well known that holocellulose specimens include some lignin portions, since lignin and carbohydrates exist in cell walls in a combined form known as lignin polysaccharides complexes (LPC) or lignin carbohydrate complexes (LCC) (Fengel and Wegener 1989).

Many important changes were observed during the process of obtaining holocellulose and alphacellulose samples. However, there are many differences between theory and practice, and this IR analysis demonstrates those differences. 
The most important bands were observed in the so-called 'fingerprint' region between $1800 \mathrm{~cm}^{-1}$ and $650 \mathrm{~cm}^{-1}$ (Table 2). The FTIR spectra of the softwoods that were examined in this study, the control specimens, and their holocelluloses and alphacelluloses from PP and PS are shown in Figs. 1 and 2, respectively. Because there were no remarkable differences observed between non-extracted wood and extracted wood specimens, only the extracted wood spectrum was used as a control specimen.

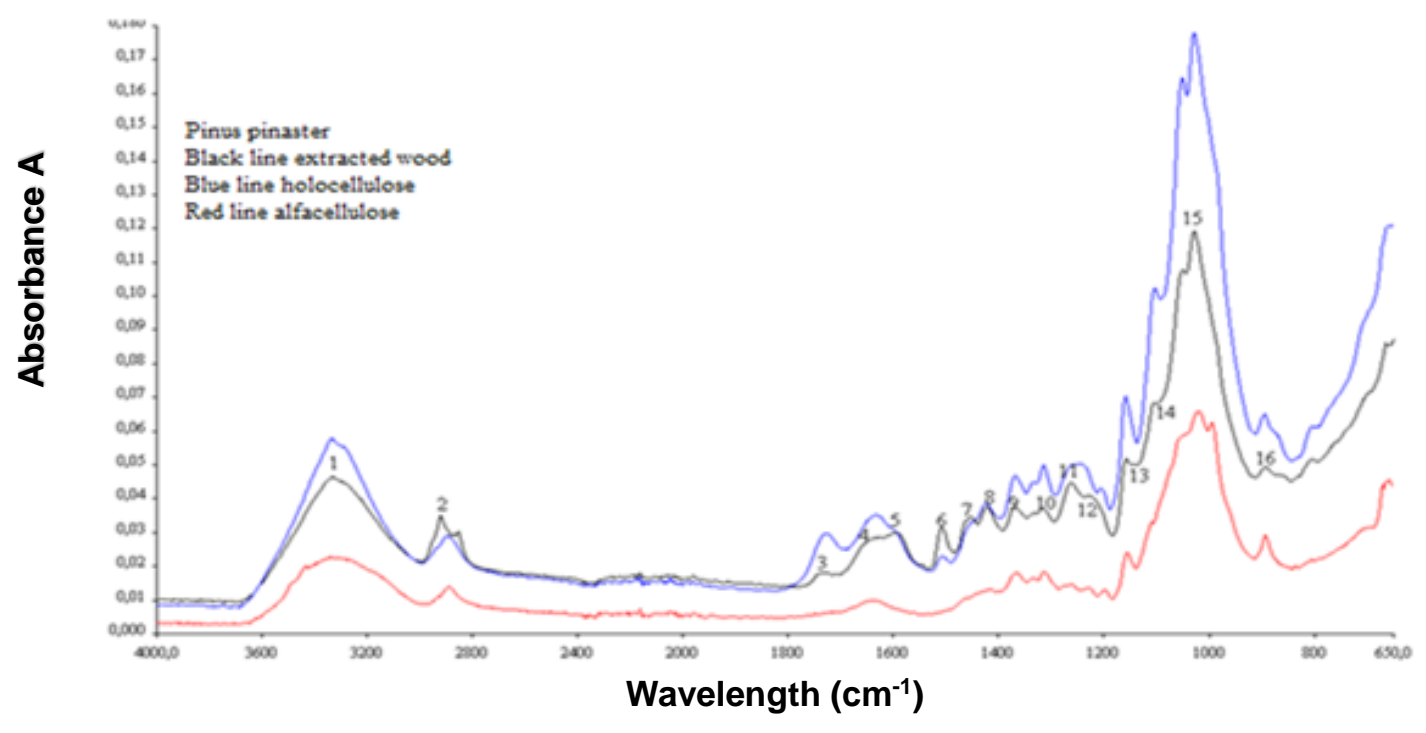

Fig. 1. IR spectra of PP wood, holocellulose, and alphacellulose

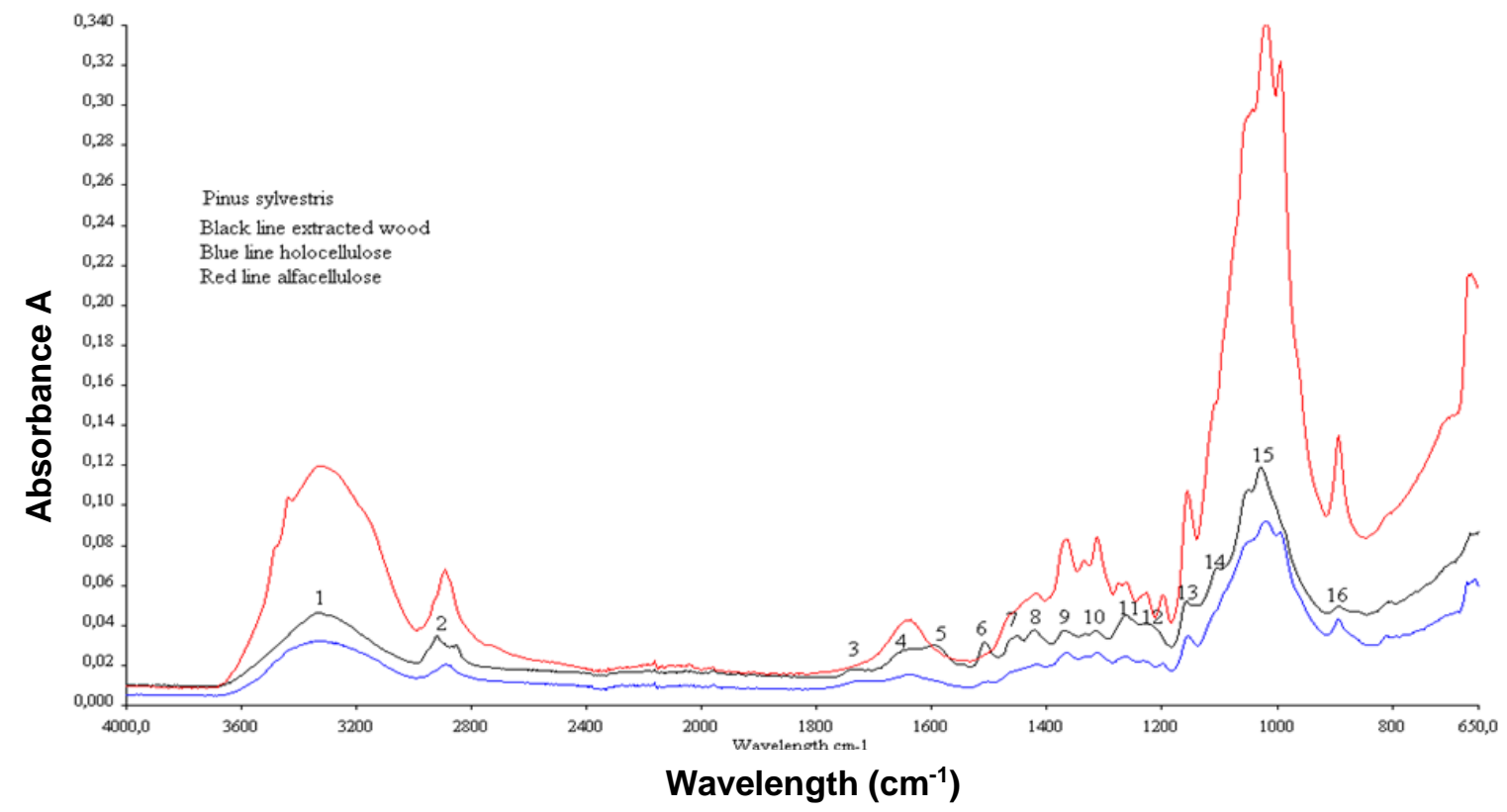

Fig. 2. IR spectra of PS wood, holocellulose, and alphacellulose 
Lignin can be regarded as a matrix, which holds cell wall components together in wood material. Softwoods have higher amounts of lignin than hardwoods (Fengel and Wegener 1989; Stark et al. 2015).

The most important difference between hardwood and softwood lignins is that lignins of hardwoods are made up of both guaiacyl (G) and syringyl (S) units, while softwoods lignins are composed only of guaiacyl units (Fengel and Wegener 1989; Evans 1991). Even though it has been accepted that most of the softwood lignins are typical Glignins, there are also S- and $p$-hydroxyphenylpropane units present to a greater or lesser extent (Fengel and Wegener 1989). Erickson et al. (1973) reported such findings for spruce (Picea abies) lignin (G:S:H = 94:1:5) and Glasser (1980) reported them for pine (Pinus taeda) lignin (G:S:H; 86:2:13) (Fengel and Wegener 1989).

After the delignification process, it was expected that the peaks associated with lignin would disappear, or at least exhibit decreased intensity (Figs. 1 and 2).

Table 2. FTIR Peak Assignments in Softwoods: PP (1) and PS (2)

\begin{tabular}{|c|c|c|c|}
\hline $\begin{array}{l}\text { Peak } \\
\text { No. }\end{array}$ & Wavenumber $\left(\mathrm{cm}^{-1}\right)$ & Assignment & Specimen \\
\hline 1 & 3336 & $\mathrm{O}-\mathrm{H}$ Stretching of bonded hydroxyl groups & 1,2 \\
\hline 2 & 2921 & $\begin{array}{l}\text { Symmetric } \mathrm{CH} \text { stretching in aromatic methoxyl } \\
\text { groups and in methyl and methylene groups of } \\
\text { side chains. }\end{array}$ & 1,2 \\
\hline 3 & $\begin{array}{l}1735 \\
1730\end{array}$ & $\mathrm{C}=\mathrm{O}$ stretching in xylans (unconjugated) & $\begin{array}{l}2 \\
1\end{array}$ \\
\hline 4 & $\begin{array}{l}1648 \\
1643\end{array}$ & $\begin{array}{l}\mathrm{H}-\mathrm{O}-\mathrm{H} \text { deformation vibration of absorbed water } \\
\text { and } \mathrm{C}=\mathrm{O} \text { stretching in lignin }\end{array}$ & $\begin{array}{l}2 \\
1\end{array}$ \\
\hline 5 & $\begin{array}{l}1596 \\
1590\end{array}$ & $\begin{array}{l}\text { Aromatic skeletal vibrations }+\mathrm{C}=\mathrm{O} \text { stretching } \\
\qquad \mathrm{S} \geq \mathrm{G}\end{array}$ & $\begin{array}{l}2 \\
1\end{array}$ \\
\hline 6 & 1507 & Aromatic skeletal vibrations in lignin & 1,2 \\
\hline 7 & $\begin{array}{l}1462 \\
1453\end{array}$ & $\mathrm{CH}_{2}$ deformation vibrations in lignin and xylan & $\begin{array}{c}2 \\
1,2\end{array}$ \\
\hline 8 & $\begin{array}{l}1421 \\
1418\end{array}$ & $\begin{array}{l}\text { Aromatic skeletal vibrations combined with } \mathrm{C}-\mathrm{H} \\
\text { in plane deformation }+\mathrm{C}-\mathrm{H} \text { deformation in lignin } \\
\text { and carbohydrates }\end{array}$ & $\begin{array}{l}1 \\
2\end{array}$ \\
\hline 9 & 1367 & $\mathrm{C}-\mathrm{H}$ deformation in cellulose and hemicellulose & 1,2 \\
\hline 10 & 1314 & $\begin{array}{c}\mathrm{C}-\mathrm{H} \text { vibration in cellulose }+\mathrm{C}_{1}-\mathrm{O} \text { vibration in } \\
\text { syringyl derivatives }\end{array}$ & 1,2 \\
\hline 11 & $\begin{array}{l}1261 \\
1259\end{array}$ & $\begin{array}{c}\text { Acetyl and carboxyl vibrations in xylan and } \mathrm{C}=\mathrm{O} \\
\text { stretching vibrations in lignin }\end{array}$ & $\begin{array}{l}1 \\
2\end{array}$ \\
\hline 12 & $\begin{array}{l}1226 \\
1223\end{array}$ & $\mathrm{C}-\mathrm{O}-\mathrm{C}$ vibration in cellulose and hemicellulose & $\begin{array}{l}1 \\
2\end{array}$ \\
\hline 13 & 1158 & $\begin{array}{l}\mathrm{O}-\mathrm{H} \text { association band in cellulose and } \\
\text { hemicelluloses }\end{array}$ & 1,2 \\
\hline 14 & 1102 & $\begin{array}{c}\mathrm{C}=\mathrm{O} \text { stretching vibration in cellulose, } \\
\text { hemicelluloses and lignin }\end{array}$ & 1,2 \\
\hline 15 & $\begin{array}{l}1026 \\
1024\end{array}$ & $\begin{array}{c}\mathrm{C}=\mathrm{O} \text { stretching vibration in cellulose and } \\
\text { hemicellulose }\end{array}$ & $\begin{array}{l}2 \\
1\end{array}$ \\
\hline 16 & 895 & $\mathrm{C}-\mathrm{H}$ deformation in cellulose & 1,2 \\
\hline
\end{tabular}

Because there is a higher content of G-units in softwoods, a higher intensity of lignin bands observed at $1507 \mathrm{~cm}^{-1}$ was attributed to the presence of coniferyl alcohol. This band is seen to be more intense than the bands located at $1590 \mathrm{~cm}^{-1}$ and $1596 \mathrm{~cm}^{-1}$ in PP and PS specimens (Figs. 1 and 2). The absorption bands at $1590 \mathrm{~cm}^{-1}$ and $1596 \mathrm{~cm}^{-1}$ in 
softwood samples were attributed to the aromatic skeletal vibration of lignin. The intensities of the bands at $1590 \mathrm{~cm}^{-1}$ (PP) and $1596 \mathrm{~cm}^{-1}$ (PS) were sharply decreased in holocelluloses and appeared as small shoulders; those bands completely disappeared in both $\alpha$-celluloses. The bands in both softwoods, which were located at $1643 \mathrm{~cm}^{-1}$ and 1648 $\mathrm{cm}^{-1}$, were shifted to $1630 \mathrm{~cm}^{-1}$ in PP and $1638 \mathrm{~cm}^{-1}$ in PS, and became more intense (Figs. 1 and 2). The absorption bands observed at $1507 \mathrm{~cm}^{-1}$, were still observed at lower intensities in both softwoods' holocelluloses, and those bands were seen as a trace in $\alpha$ celluloses of both. The band observed at $1261 \mathrm{~cm}^{-1}$ can be attributed to G-ring breathing,$\mathrm{C}-\mathrm{O}$ stretching in lignin, and $\mathrm{C}-\mathrm{O}$ linkage in G-aromatic methoxyl groups (Pandey and Pitman 2003). It was still present in holocellulose and $\alpha$-cellulose samples in PP and PS, but the intensities were considerably decreased (Figs. 1 and 2).

There were two tiny peaks at 1462 and $1453 \mathrm{~cm}^{-1}$ in PS wood. After delignification, these peaks combined to form a wide shoulder (Fig. 2). However, in the PP samples, there was a small peak at $1453 \mathrm{~cm}^{-1}$ and the same peak turned into a wide shoulder, losing its intensity in the holocellulose and $\alpha$-cellulose samples (Fig. 1). The bands at $1421 \mathrm{~cm}^{-1}$ and $1418 \mathrm{~cm}^{-1}$ in PP and PS were assigned to the C-H deformation in methoxyl and aromatic skeletal vibrations in lignin (Faix 1992; Traoré et al. 2018). These bands indicate the presence of aromatic methoxyl groups in the softwood lignin structure; they were still observed after $\mathrm{NaClO}_{2}$ delignification (Wise and John 1952) and even after two-step $\mathrm{NaOH}$ extraction. However, the absorbance of those bands was decreased in the holocellulose and $\alpha$-cellulose specimens. The continued presence of these bands indicated the presence of lignin or lignin carbohydrate complexes (LCCs). In softwoods, all lignin moieties contain LCCs. A predominance of benzyl ether linkages has been reported in softwood LCCs, whereas esters and phenyl glycosidic bonds were dominant in deciduous species (Fengel and Wegener 1989).

The bands located at $1261 \mathrm{~cm}^{-1}$ in PP and $1259 \mathrm{~cm}^{-1}$ in PS can be attributed to guaiacyl ring breathing, as well as the $\mathrm{C}-\mathrm{O}$ stretch in lignin and $\mathrm{C}-\mathrm{O}$ linkage in guaiacyl aromatic methoxyl groups (Table 1). According to Pandey (1999) and Pandey and Pitman (2003), softwood lignin, which is called G-lignin, is largely based on coniferyl alcohol units, and absorbs near the 1270 and $1230 \mathrm{~cm}^{-1}$ regions. In this study, bands were observed at 1261 and at $1259 \mathrm{~cm}^{-1}$ in PP and PS wood samples as large peaks, and small shoulders were also observed following peaks at 1226 and $1223 \mathrm{~cm}^{-1}$ (Figs. 1 and 2). Those small shoulders were attributed to the S-type of lignin that is the major type lignin in hardwoods (Pandey 1999; Schwanninger et al. 2004).

Based on previous reports (Jin et al. 2006; Tarasov et al. 2019), over 50\% of lignin units in softwood bond molecularly to cellulose moieties. In softwoods, all lignin moieties are involved in LCCs, whereas in hardwoods and herbaceous plants, the LCCs constitute approximately $47 \%$ to $66 \%$ and $16 \%$ to $35 \%$ of total lignin, respectively. It is reported that while benzyl ether linkages are dominant in softwood LCCs, the esters and phenyl glycosidic bonds are dominant in deciduous species (Tarasov et al. 2019). It is also reported that softwood species contain LCCs with two different structures of lignin: lignin-xylan and lignin-glucomannan. However, hardwood species mainly contain xylan-lignin and cellulose-lignin complexes (Tarasov et al. 2019).

During the delignification process, wood components undergo extensive changes. The duration of processing is important to structural changes in wood, as is the temperature to which the wood is exposed. Even though the aim of delignification is to remove lignin and preserve polysaccharides, there is an inevitable loss of polysaccharides due to LCCs. Peak absorbance is expected at spectra belonging to hemicellulose and cellulose, as in 
wood spectra after delignification, but it has been observed that many of the peaks shifted and intensities decreased (Figs. 1 and 2).

After delignification, the infrared bands at 1730 and $1735 \mathrm{~cm}^{-1}$ in PP and PS wood samples shifted to 1727 and $1730 \mathrm{~cm}^{-1}$, respectively. Although the intensities of both bands decreased after delignification, notably that of the band at $1730 \mathrm{~cm}^{-1}$ in PS holocellulose displayed the highest decrease. During delignification with sodium chlorite in acidic medium, oxidative reactions occur, causing cleavage of polysaccharide chains and the production of new functional groups (Fengel and Wegener 1989). Furthermore, following delignification, two steps of $\mathrm{NaOH}$ extractions (TAPPI T203 cm-99 (2009)) caused 1730 and $1735 \mathrm{~cm}^{-1}$ bands to disappear in the $\alpha$-celluloses of both samples (Figs. 1 and 2).

The band that is referred to as $\mathrm{C}-\mathrm{H}$ deformation in cellulose and hemicellulose seen in both wood species at $1367 \mathrm{~cm}^{-1}$, became more intense in those holocelluloses, but the intensity was decreased in those $\alpha$-celluloses (Figs. 1 and 2).

The band at $1158 \mathrm{~cm}^{-1}$ was observed as a shoulder in both wood samples and was generated by $\mathrm{C}-\mathrm{O}-\mathrm{C}$ vibration in cellulose and hemicellulose. However, in both samples, these bands became more apparent and sharp in holocelluloses and $\alpha$-celluloses. These bands were slightly shifted for each of the $\alpha$-celluloses of the PP and PS samples, and they were located at $1155 \mathrm{~cm}^{-1}$ in PS and PP (Figs. 1 and 2).

The highest band, located at $1024 \mathrm{~cm}^{-1}$ in PP and at $1026 \mathrm{~cm}^{-1}$ in PS, is referred to as the $\mathrm{C}=\mathrm{O}$ stretching vibration in cellulose, hemicelluloses, and lignin. These bands were split in two parts and both were shifted to $1019 \mathrm{~cm}^{-1}$; new bands appeared at $993 \mathrm{~cm}^{-1}$ (Figs. 1 and 2). During acidified sodium chlorite delignification, the lignin becomes soluble, changing its structure because of substitution and oxidative reactions (Fengel and Wegener 1989). Because of those reactions, new bands such as that at $993 \mathrm{~cm}^{-1}$ occur due to CO stretching in cellulose (Herrera et al. 2014).

The bands observed at $895 \mathrm{~cm}^{-1}$ in both softwoods were attributed to $\mathrm{C}=\mathrm{O}$ stretching vibration in cellulose, while their intensities were slightly decreased in the holocellulose samples. It appears that some low molecular weight cellulose portions may be removed with the polyoses during the delignification process.

Although there were no marked visible differences between wood and holocellulose specimens (Figs. 1 and 2), there were some noticeable differences between the maximum peak heights of the spectra between the wood and holocellulose specimens. Table 3 shows the ratios that were obtained. The lignin peak heights at $1507 \mathrm{~cm}^{-1}$ were normalized against the carbohydrate reference peak heights at $1730 \mathrm{~cm}^{-1}$ (PP) and 1735 $\mathrm{cm}^{-1}$ (PS); those same peaks were compared to $1367 \mathrm{~cm}^{-1}, 1158 \mathrm{~cm}^{-1}$, and $895 \mathrm{~cm}^{-1}$ in PP and PS, respectively.

The ratios of the peak heights at wavenumbers 1507 and $1730 \mathrm{~cm}^{-1}$ were calculated as 1.34 and 0.77 for PP wood and holocellulose specimens, respectively, as seen in Table 3. The peak at $1730 \mathrm{~cm}^{-1}$ was assigned to the $\mathrm{C}=\mathrm{O}$ stretching in xylans in PP and PS and the peak at $1507 \mathrm{~cm}^{-1}$ was assigned for the $\mathrm{C}=\mathrm{C}$ stretching in lignin. Thus, the decrease of the ratio from 1.34 to 0.77 means that a remarkable degradation occurred in lignin compared to xylan in PP holocellulose, as noted in Table 3. In other words, the removal rate of lignin due to xylans was calculated as higher than $42.5 \%$ in the PP wood specimens (Table 3). However, the same ratio $\left(1507 / 1735 \mathrm{~cm}^{-1}\right)$ was calculated as $35.3 \%$ for PS wood (Table 3). It means that xylans were removed more or lignin was retained better during the PS delignification process compared to the PP delignification process. 
Table 3. Ratio of the Intensity of the Lignin Associated Bands with Carbohydrate Bands for Holocellulose Specimens from PP and PS

\begin{tabular}{|c|c|c|c|c|}
\cline { 2 - 5 } \multicolumn{1}{c|}{} & \multicolumn{4}{c|}{ Reference Peaks $\left(\mathbf{c m}^{-1}\right)$} \\
\hline Specimen & $\mathbf{1 5 0 7 / 1 7 3 0}$ & $\mathbf{1 5 0 7 / 1 3 6 7}$ & $\mathbf{1 5 0 7 / 1 1 5 8}$ & $\mathbf{1 5 0 7 / 8 9 5}$ \\
& & & & 0.54 \\
\hline PP Wood & 1.34 & 0.78 & 0.60 & 0.35 \\
\hline PP Holocel. & 0.77 & 0.49 & $-(45) \%$ & $-(35.18) \%$ \\
\hline & $-(42.54) \%$ & $-(37.21) \%$ & $1507 / 1158$ & $1507 / 895$ \\
\hline PS Wood & $1507 / 1735$ & $1507 / 1367$ & & 0,54 \\
\hline PS Holocel. & 1,47 & 0,80 & 0,55 & 0,28 \\
& $-(33.33 \%)$ & $-(42.50 \%)$ & $-(38.18 \%)$ & $-(48.15 \%)$ \\
& & & & \\
\hline
\end{tabular}

The ratio of the peak heights at wavenumbers $1507 / 1367 \mathrm{~cm}^{-1}$ were calculated as 0.78 and 0.49 for PP wood and holocellulose specimens, respectively, and the same ratio was calculated as 0.80 and 0.46 for PS wood and holocellulose specimens (Table 3). According to these findings, the loss of holocellulose was higher during PS delignification as noticed at Table 3 .

Besides the ratio of the peaks' height at the bands $1507 / 1158 \mathrm{~cm}^{-1}$ was calculated as 0.6 and 0.33 for PP wood and holocellulose, respectively. It was calculated that the holocellulose process caused a $45 \%$ decrease in the mentioned ratio on the behalf of lignin removal. The same ratio was determined as 0.55 and 0.34 for PS wood and holocellulose specimens, respectively. A $37.3 \%$ decrease was determined in those bands' ratio for PS as seen in Table 3. The peak at wavenumber $895 \mathrm{~cm}^{-1}$ was attributed to $\mathrm{C}-\mathrm{H}$ deformation in cellulose and the ratio of $1507 / 895 \mathrm{~cm}^{-1}$ was 0.54 for PP wood and 0.35 for holocellulose specimens. There was a $35.7 \%$ decrease observed after delignification of PP holocellulose specimen. The same ratio was determined as 0.54 and 0.28 for PS wood and holocellulose, respectively, and the decrease was calculated as $49.3 \%$ after delignification for PS specimen (Table 3).

\section{Thermal Analysis}

Wood flour and its components, such as non-extracted wood, extracted wood, holocellulose, and $\alpha$-cellulose, are used to improve the thermal stability of the polymer combinations as a loader or support (Tserki et al. 2005; Poletto et al. 2012). The materials used in the polymer matrix used for the production of thermoplastic polymers are required to withstand temperatures of approximately $200{ }^{\circ} \mathrm{C}$. Therefore, it is important to identify the thermal degradation profile of fiber to be used in industrial applications.

Temperature is an important parameter in the thermal degradation of wood, as well as processing time, atmospheric pressure, and water content. The water content of wood has an important impact on its thermal softening. Water content depends on properties such as the reduction sorption, dry weight, and size stability of the wood. Thermal reactions in wood specimens and their components were measured using a differential thermal analyzer (DTA). Thermal gravimetric data corresponding to the untreated and extracted woods, holocellulose, and $\alpha$-cellulose of PS and PP are shown in Figs. 3 to 6.

Using the thermal graphs, the thermal characteristics of the specimens were determined by mass losses and the highest peak temperatures as shown in Table 4 (Figs. 3 to 6). The thermal softening temperatures of the softwood specimens and their components 
ranged from 180 to $380{ }^{\circ} \mathrm{C}$. The presence of moisture was indicated as a peak below 180 ${ }^{\circ} \mathrm{C}$. As the moisture content increased, the softening temperature decreased. The conversion of wood components into pyrolysis by degradation products started at $270{ }^{\circ} \mathrm{C}$ and increased with increasing temperature above $500{ }^{\circ} \mathrm{C}$. Although thermograms showed an endothermic reaction in general, with a maximum peak indication of $120{ }^{\circ} \mathrm{C}$ to $150{ }^{\circ} \mathrm{C}$, the initial temperature started at $220^{\circ} \mathrm{C}$. This observation indicates that strongly absorbed water evaporated. Exothermic peaks at $200{ }^{\circ} \mathrm{C}$ to $250{ }^{\circ} \mathrm{C}$ and $280{ }^{\circ} \mathrm{C}$ to $320^{\circ} \mathrm{C}$ were higher than peaks at $400{ }^{\circ} \mathrm{C}$, due to the degradation of wood components (Fengel and Wegener 1989).

The TGA-DTG thermograms reflect three major processes (Table 4). The first phase was removal of water from cellulosic specimens occurred via evaporation (20 to 150 ${ }^{\circ} \mathrm{C}$ ). The second degradation phase was pyrolysis (occurred around 188 to $426{ }^{\circ} \mathrm{C}$ ) due to dehydration and depolymerization of the cell wall components of the cellulosic material (Phinichka and Kaenthong 2018). The third phase was carbonization of those compounds and was given in Table 4. According to Beall and Eickner (1970), the residue compounds contain active site primarily of charcoal for further secondary reactions at above from 500 to $1017^{\circ} \mathrm{C}$.

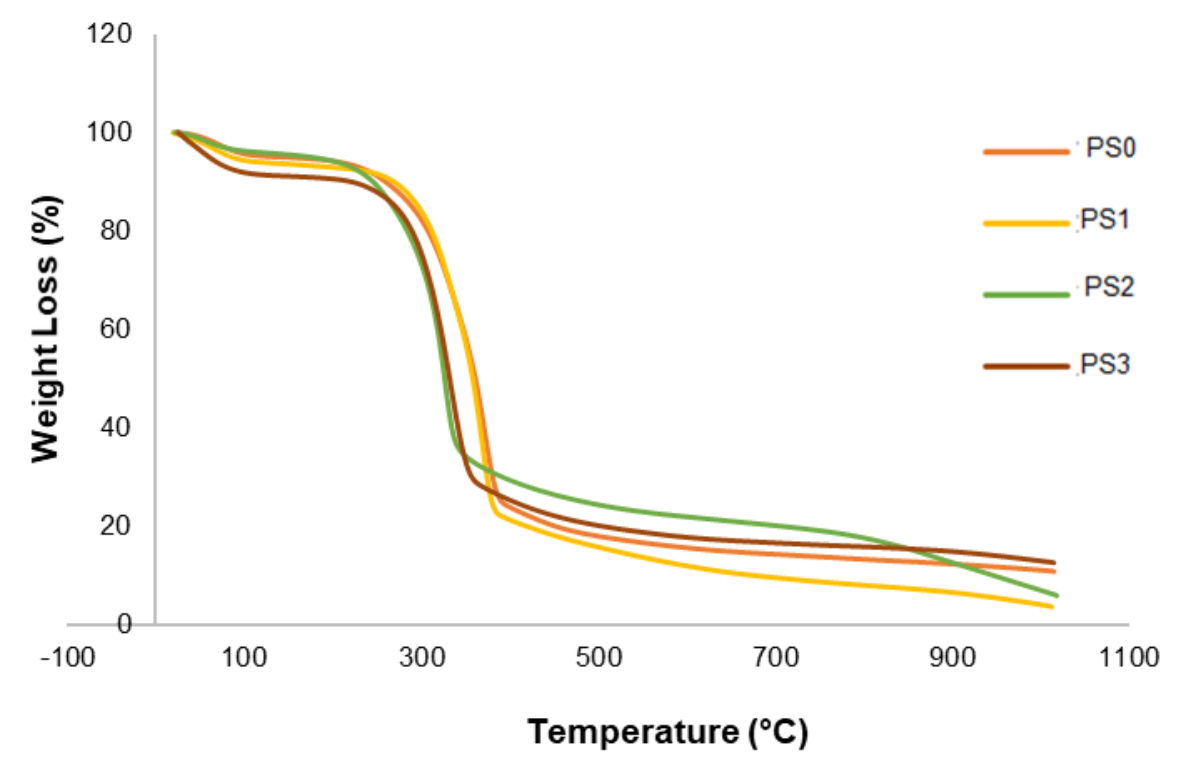

Fig. 3. Thermal analysis of Pinus sylvestris wood components PS0: Non-extracted wood; PS1: Extracted-wood; PS2: Holocellulose; and PS3: $\alpha$-Cellulose 


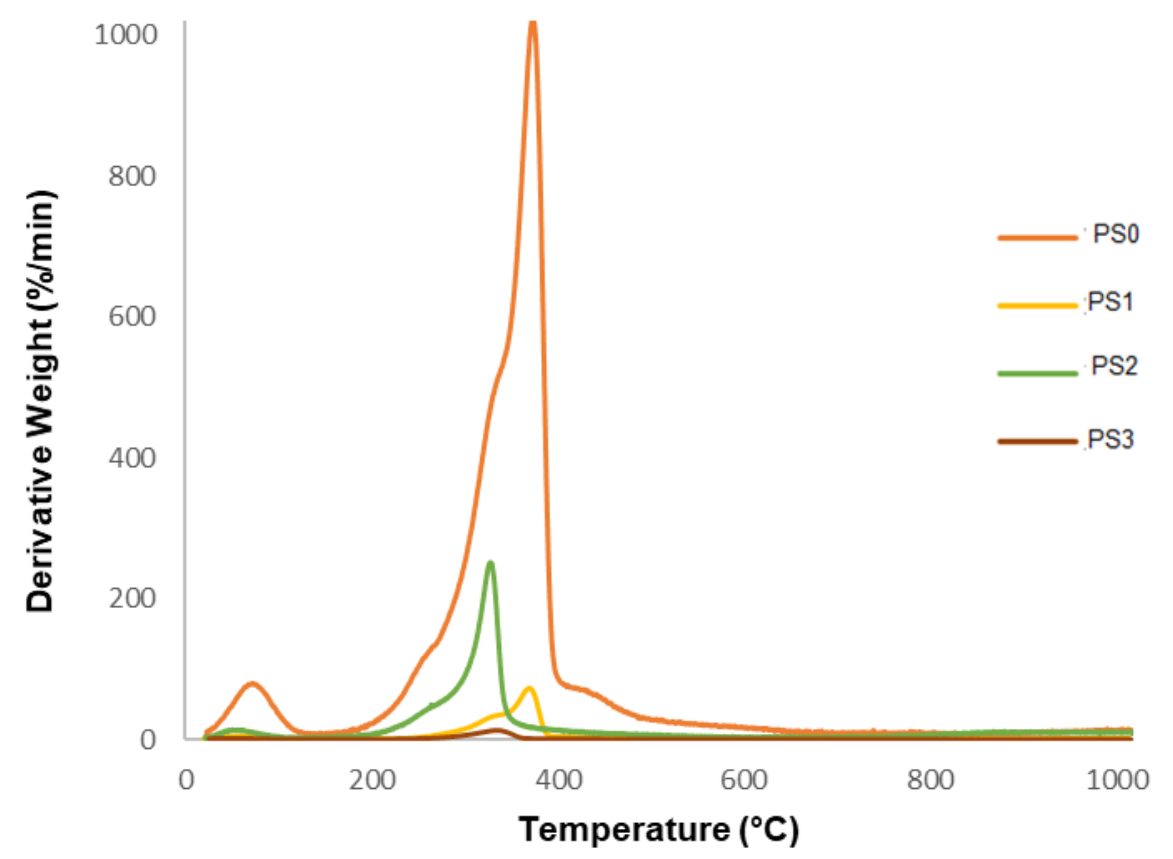

Fig. 4. DTG profiles of Pinus sylvestris wood components: PS0: Non-extracted wood; PS1: Extracted-wood; PS2: Holocellulose; and PS3: $\alpha$-Cellulose

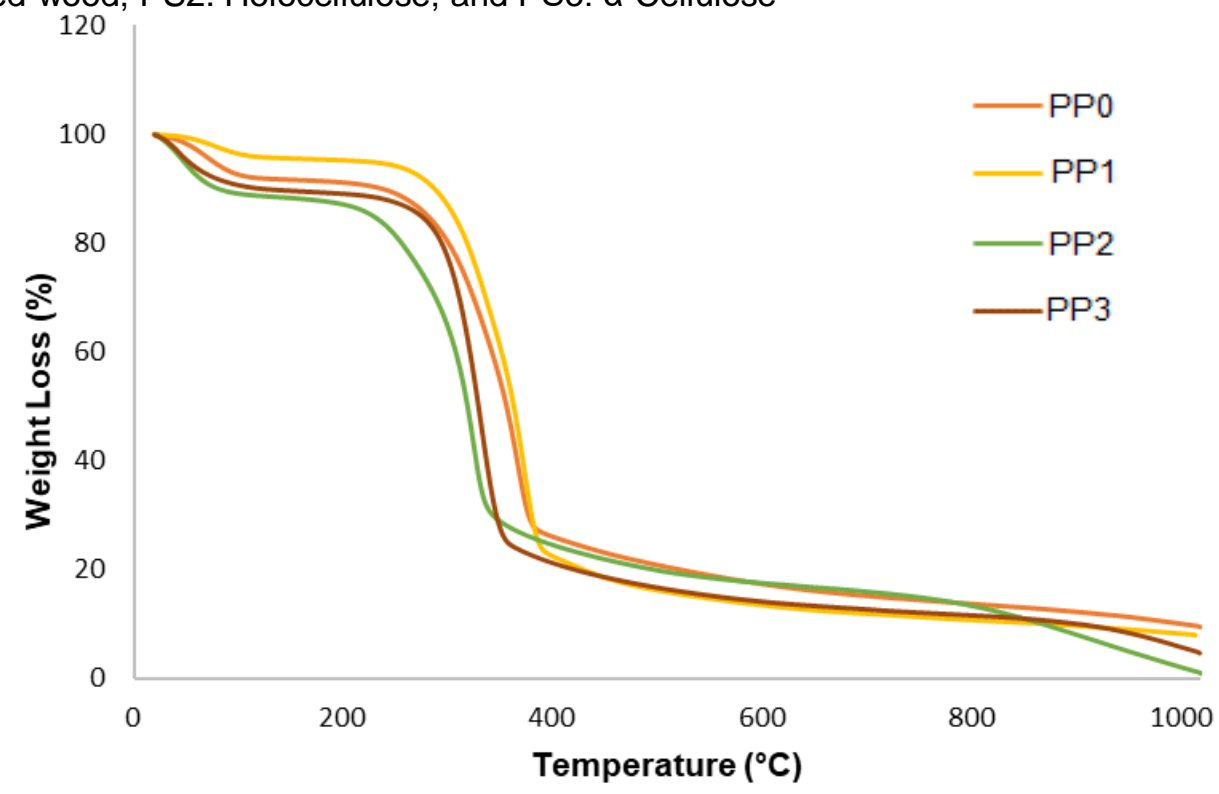

Fig. 5. Thermal analysis of Pinus pinaster wood components; PP0: Non-extracted wood; PP1: Extracted-wood; PP2: Holocellulose; and PP3: $\alpha$-Cellulose 


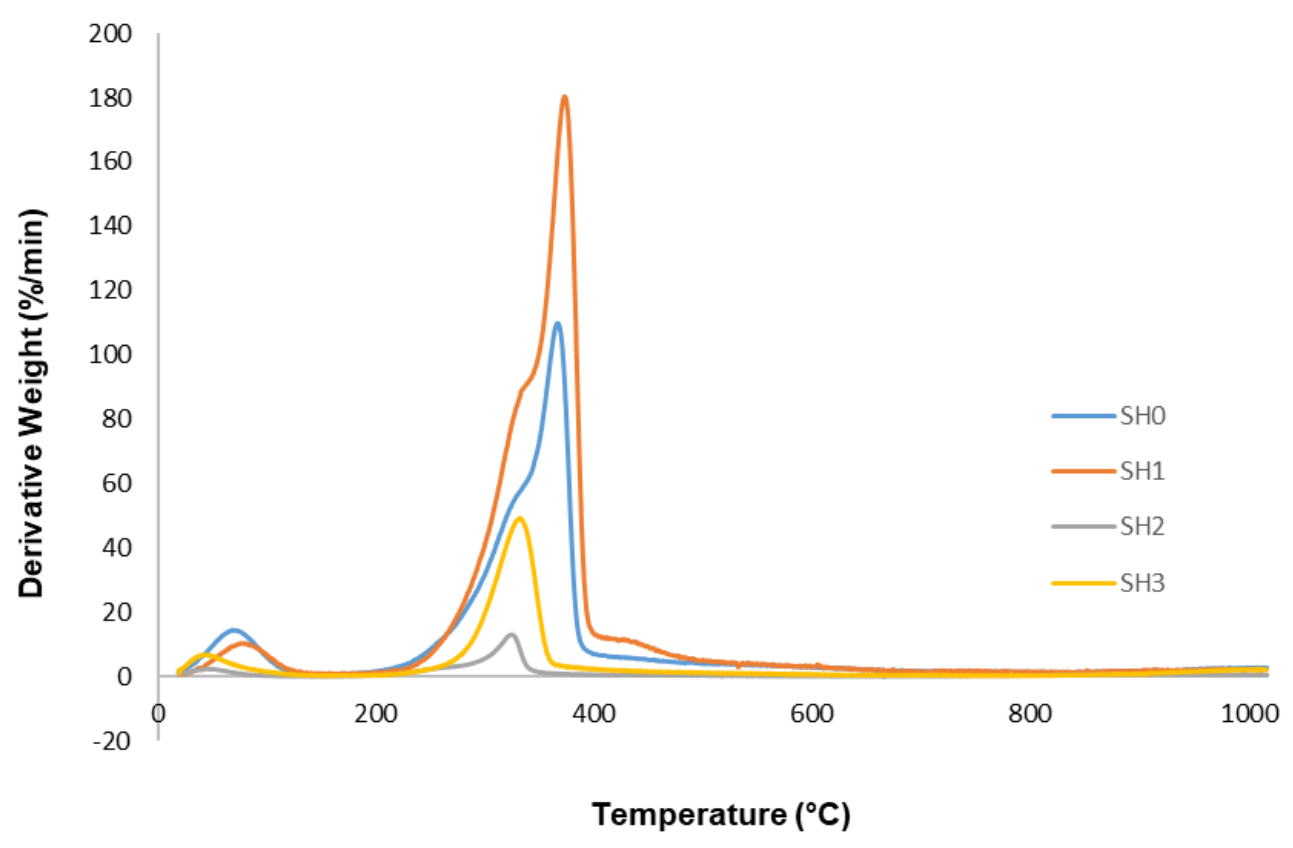

Fig. 6. DTG profiles of Pinus pineaster wood components: PP0: Non-extracted wood; PP1: Extracted-wood; PP2: Holocellulose; and PP3: $\alpha$-Cellulose

\section{Water loss}

The effects of thermal decomposition on hemicellulose were remarkable, due to its random amorphous structure, which means that it was easily hydrolyzed. The moisture content is also an important factor (Ornaghi et al. 2014). Wood flour and its compounds in PP and PS lost water at temperatures of $100{ }^{\circ} \mathrm{C}$ and above, up to $130{ }^{\circ} \mathrm{C}$. While water loss from holocellulose of PS was $4.04 \%$ at the lowest temperature of $115{ }^{\circ} \mathrm{C}$, loss from holocellulose PP was $1.48 \%$ at a temperature of $126.9{ }^{\circ} \mathrm{C}$. The smallest amount of water loss was seen in holocellulose, and the largest amount of water loss was observed in $\alpha$ cellulose (Table 4). This may have been because the high moisture content of hemicellulose in holocellulose is removed during dry matter operations at low temperatures.

The moisture content of PS holocellulose was higher than that of PP, possibly because of thermal decomposition with high mass loss at a lower peak temperature during the first degradation. The minimal amount of water removed from the holocellulose can be explained by the removal of large amounts of water from the hemicellulose.

The lowest level of water removal was shown to be in holocellulose within other cell wall constituents. This indicates that the amount of water absorbed was less in the holocellulose than in the other cell wall constituents (Table 4).

The $\alpha$-cellulose of softwoods contains relatively high amounts of hemicellulose and residual lignin. Reduction of $\alpha$-cellulose may be explained by the loss of accompanying compounds at temperatures above $100{ }^{\circ} \mathrm{C}$. Therefore, the content of pure $\alpha$-cellulose remains constant up to $150{ }^{\circ} \mathrm{C}$ (Fengel and Wegener 1989). The highest removal of water in $\alpha$-cellulose was $8.7 \%$ in PS and $11.0 \%$ in PP. The highest water loss of all components occurred from $\alpha$-cellulose. 


\section{Mass loss in the first degradation stage}

Cyclohexane-EtOH-extracted wood, extracted wood, holocellulose, and $\alpha$ cellulose in the PP and PS were characterized by initial $\left(186^{\circ} \mathrm{C}\right)$ and finishing $\left(426.3{ }^{\circ} \mathrm{C}\right)$ temperatures, using thermogravimetric analysis in the first degradation stage. The thermal behaviors of the compounds were different. The mass loss of cyclohexane-EtOH-extracted PS $\left(377.3{ }^{\circ} \mathrm{C}\right)$ increased $5.03 \%$ over that of PP $\left(369{ }^{\circ} \mathrm{C}\right)$, and had lower degradation peak temperatures with a difference of $3.39^{\circ} \mathrm{C}$.

The large amount of unextracted wood is caused by the thermal degradation temperature of wood (Paletto 2014). The mass loss of cyclohexane-EtOH-extracted PP was higher by $1.76 \%$ with increasing degradation peak temperature $\left(373.0{ }^{\circ} \mathrm{C}\right)$, with a difference of $2.15{ }^{\circ} \mathrm{C}$ over that of PS $\left(370.8{ }^{\circ} \mathrm{C}\right)$. The initial degradation temperature of extract-free specimens increased noticeably from 188.9 to $219.37{ }^{\circ} \mathrm{C}$ for PS, and from 188.7 to $222.2^{\circ} \mathrm{C}$ for PP.

Holocellulose, which encompasses cellulose and hemicellulose, had the lowest degradation peak temperature of all the compounds, due to the ease of decomposition of hemicellulose. Mass loss of PS holocellulose was $1.69 \%$ higher, with a peak degradation temperature differential of $0.48{ }^{\circ} \mathrm{C}$ over PP. Cellulose is more resistant to heat, probably due to its crystalline fraction structure (Esteves and Pereire 2009; Janoobi et al. 2009). The peak degradation temperature of cellulose was higher, at around $330{ }^{\circ} \mathrm{C}$ to $337{ }^{\circ} \mathrm{C}$, than those of the other components. For the $\alpha$-cellulose of PP, the mass loss was much larger $(1.96 \%)$ with increasing degradation peak temperature differentials $\left(7.23{ }^{\circ} \mathrm{C}\right)$ than that of PS. This indicates that $\alpha$-cellulose can degrade easily and it is a positive situation in terms of environmental protection.

The maximum peak height in the degradation phase was between temperatures of 326 and $375^{\circ} \mathrm{C}$, and mass loss was 68.9 to $83.2 \%$ in all of the compounds. Non-extracted wood and holocellulose specimens from PS had a mass loss between 8.36 and $20.41 \%$ at 455.4 to $1017^{\circ} \mathrm{C}$ in the carbonization step (Table 4). It was thought that the charcoal to be glow and consumed at above $500{ }^{\circ} \mathrm{C}$ and supported nonluminous flame at $1000{ }^{\circ} \mathrm{C}$ by the combustion of hydrogen and carbon monoxide (Beall and Eickner 1970).

Holocellulose contains cellulose and hemicellulose compounds. It was determined that the high amount of PS2 holocellulose detected by chemical analysis showed high mass loss in thermal degradation (Table 1 and 4). This explains the situation of a linear relationship between the PS and PP holocelluloses and alphacellulose's quantities and thermal degradation with their mass losses. A similar situation was existed in PS and PP extracted woods.

Table 4. Characteristic Temperatures and Mass Losses for the Thermal Degradation Reaction in the Softwood Samples

\begin{tabular}{|c|c|c|c|}
\hline Name & $\begin{array}{c}\text { First phase Water Loss } \mathrm{Ti} \\
\text { to } T \text { T }\left({ }^{\circ} \mathrm{C}\right) ; \mathrm{m} \% ; \text { Peak } T\left({ }^{\circ} \mathrm{C}\right)\end{array}$ & $\begin{array}{c}\text { Second Degradation Phase } \\
\text { Ti to Tf }\left({ }^{\circ} \mathrm{C}\right) ; \quad \mathrm{m} \% ; \mathrm{Peak} T\left({ }^{\circ} \mathrm{C}\right)\end{array}$ & $\begin{array}{c}\text { Third Degradation } \\
\text { Phase } T \text { to } T \text { Tf }\left({ }^{\circ} \mathrm{C}\right) ; \mathrm{m} \%\end{array}$ \\
\hline PS0 & 22.8 to $128.3 ; 4.90 ; 77.2$ & 188.9 to $422.9 ; 71.9 ; 377.3$ & 422.9 to $1014 ; 11.17$ \\
\hline PS1 & 19.6 to $123.3 ; 6.13 ; 53.1$ & 219.4 to $420.0 ; 72.8 ; 370.8$ & 420.0 to $1010 ; 16.21$ \\
\hline PS2 & 21.6 to $115.0 ; 4.04 ; 58.0$ & 188.7 to $407.2 ; 65.7 ; 326.4$ & 407.2 to $1017 ; 22.94$ \\
\hline PS3 & 25.6 to $126.7 ; 8.70 ; 52.5$ & 206.1 to $410.8 ; 68.5 ; 337.2$ & 410.8 to $1014 ; 15.62$ \\
\hline PP0 & 19.0 to $126.4 ; 8.12 ; 83.2$ & 188.7 to $426.3 ; 66.9 ; 369.0$ & 426.3 to $1014 ; 14.77$ \\
\hline PP1 & 19.9 to $130.9 ; 4.17 ; 63.3$ & 222.2 to $423.5 ; 74.5 ; 373.0$ & 423.5 to $1011 ; 12.44$ \\
\hline PP2 & 22.7 to $126.9 ; 1.48 ; 48.6$ & 188.6 to $416.7 ; 64.0 ; 268.9$ & 416.7 to $1017 ; 22.51$ \\
\hline PP3 & 19.1 to $127.6 ; 11.0 ; 47.1$ & 223.6 to $412.6 ; 68.4 ; 333.6$ & 412.6 to $1013 ; 15.51$ \\
\hline
\end{tabular}




\section{CONCLUSIONS}

The chemical and thermal characterizations of Pinus sylvestris and Pinus pinaster non-extracted wood, cyclohexane-EtOH-extracted wood, holocellulose, and alphacellulose were conducted by quantifying the chemical components, FTIR spectra, and TGA-DTG thermograms. These data indicated the way to estimate the quality of wood for the species growing in Turkey.

In terms of quantitative chemical characterization, the amounts of holocellulose, alphacellulose, and ash in PS were higher than those in PP, but lignin and cyclohexaneEtOH solubility amounts were lower.

During the processes of delignification and isolation of cellulose, many oxidative and hydrolytic degradation reactions took place. As a result, new functional groups were introduced.

1. Delignification exhibited similar behavior in both softwood samples. Lignin bands at $1596 \mathrm{~cm}^{-1}$ were removed, and lignin bands at $1507 \mathrm{~cm}^{-1}$, referred to as guaiacyl (G) lignins, were observed in the spectra of the holocelluloses of both softwoods. However, these bands were removed in $\alpha$-cellulose specimens.

2. The spectra of $\alpha$-celluloses still had functional groups that belong to polyoses, indicating that even two-step alkali treatments had not effectively removed all polyoses.

3. In the first step, the removal of water from the samples occurred between $19{ }^{\circ} \mathrm{C}$ to $131{ }^{\circ} \mathrm{C}$. Evaporation, softening, and degradation of water absorbed by wood and their components occurred most strongly at $188{ }^{\circ} \mathrm{C}$ to $426.3{ }^{\circ} \mathrm{C}$. The maximum peak heights of the degradation phase were between $326{ }^{\circ} \mathrm{C}$ to $377.3{ }^{\circ} \mathrm{C}$. The carbonization step occurred in between $426.3{ }^{\circ} \mathrm{C}$ and $1017{ }^{\circ} \mathrm{C}$.

4. The water loss of untreated PS flour was higher than that of PP. While the lowest amount of water was removed in holocellulose, the highest amount of water removed was in $\alpha$-cellulose at the low temperature.

5. The extract-free specimens for PS exhibited thermal stability at lower temperature than that of PP. It was found that holocellulose of PS degraded faster than that of PP. The $\alpha$-cellulose of PP degraded at lower temperature than that of PS.

6. The PS wood flour and other wood components degraded at lower temperature than that of PP in the carbonization step.

\section{REFERENCES CITED}

Alves, A., Santos, S., Simoes, R., and Rodrigues, J. (2018). "Characterization of residual lignin in cellulose isolated by the diglyme method from tree Pinus species by IR spectroscopy and analytical pyrolysis," Holzforschung 72(2), 91-96. DOI: 10.1515/hf2017-0031

Akkemik, U. (2018). Türkiye’nin Doğal-ekzotik Ağaç ve Calıları [Turkey's NaturalExotic Trees and Shrubs], T. C. Orman ve Su İşleri Bakanlığı Orman Genel Müdürlüğü [T. C. Ministry of Forestry and Water Affairs General Directorate of Forestry], Ankara, Turkey. 
As, N., Koc, K. H., Dogu, D., Atik, C., Aksu, B., and Erdinler, S. (2001). "Türkiye'de yetişen endüstriyel öneme sahip ağaçların anatomik, fiziksel, mekanik ve kimyasal özellikleri [The chemical, mechanical, physical and anatomical properties of economically important wood in Turkey]," Journal of Istanbul University Faculty of Forestry B Series 51(1), 71-88.

Beall, F. C and Eickner, H. W. (1970). "Thermal degradations of wood components: Review of the literature," Forest Service Research paper FPL 130 1-27.

Cobas, A. C., Felissia, F. E., Monteoliva, S., and Area, M. C. (2013). "Optimization of the properties of poplar and willow chemimechanical pulps by a mixture design of juvenile and mature wood," BioResources 8(2), 1646-1656. DOI: 10.15376/biores.8.2.1646-1656

Erickson, M., Larsson, S., and Miksche, G. E. (1973). "Gaschromatographische Analyse von Ligninoxydationsprodukten VIII. Zur Struktur des Lignins der Fichte [Gas chromatographic analysis of lignin oxidation products VIII. To the structure of the lignin of the spruce], Acta Chemica Scandinavica 27, 903-914. DOI:

10.3891/acta.chem.scand.27-0903

Esteves, B., and Pereire, H. (2009). "Heat treatment of wood," BioResources 4(1), 370404. DOI: $10.15376 /$ biores.4.1.370-404

Evans, P. A. (1991). "Differentiating hard from soft woods using Fourier transform infrared and Fourier transform Raman spectroscopy," Spectrochim Acta 47A(9/10), 1441-1447. DOI: 10.1016/0584-8539(91)-80235-B

Faix, O. (1991). "Classification of lignins from different botanical origins by FTIR spectroscopy," Holzforschung 45(s1), 21-27. DOI: 10.1515/hfsg.1991.45.s1.21

Faruk, O., Bledzki, A. K., Fink, H., and Sain, M. (2012). "Biocomposites reinforced with natural fibers: 2000-2010," Prog. Polym. Sci. 37, 1552-1596. DOI:

10.1016/j.progpolymsci.2012.04.003.

Fengel, D., and Wegener, G. (1989). "Chemical composition and analysis," in: Wood Chemistry, Ultrastructure, Reactions, Walter de Gruyter, Berlin, Heidelberg, Germany, pp. 527-531.

Glasser, W. G. (1980). "Lignin," in: Pulp and Paper Chemistry and Chemical Technology, Vol. 1, $3^{\text {rd }}$ Edition, J. P. Casey (ed.), Wiley-Interscience, New York, NY, USA, pp. 39-111.

Gurboy, B. (2000). “Chemical composition of Pintıs pinaster," Journal of Istanbul University Faculty of Forestry Series A 50(2), 105-112.

Hafizoglu, H., and Usta, M. (2005). "Chemical composition of coniferous wood species occurring in Turkey," Holz als Roh- und Werkstoff 63(1), 83-85. DOI: 10.1007/s00107-004-0539-1

Harrington, K. J., Higgins, H. G., and Michell, A. J. (1964). "Infrared spectra of Eucalyptus regnans F. Muell. and Pinus radiata D. Don," Holzforschung 18(4), 108113. DOI: $10.1515 / \mathrm{hfsg} .1964 .18 .4 .108$

Herrera, R., Erdocia, X., Llano-Ponte, R., and Labidi, J. (2014). "Characterization of hydrothermally treated wood in relation to changes on its chemical composition and physical properties," Journal of Analytical and Applied Pyrolysis 107, 256-266. DOI: 10.1016/j.jaap.2014.03.010

Janoobi, M., Jalaludin, H., Alireza, S., Manjuari, M., and Oksman, K. (2009). "Chemical composition, crystallinity and thermal degradation of bleached and unbleached kenaf bast (Hibiscus cannabinus) pulp and nanofibers," BioResources 4(2), 626-639. DOI: 10.15376/biores.4.2.626-639 
Kiliç, A., Sariusta, S. E., and Hafizoglu, H. (2010). "Chemical structure of compression wood of Pinus sylvestris, P. Nigra and P. Brutia," Journal of Bartin University Faculty of Forestry 12(18), 33-39.

Ornaghi, Jr., H. L., Poletto, M. P., Zattera, A. J., and Amico, S. C. (2014). "Correlation of the thermal stability and the decomposition kinetics of six different vegetal fibers," Cellulose 21, 177-188. DOI: 10.1007/s10570-013-0094-1

Pandey, K. K. (1999). "A study of chemical structure of soft and hardwood and wood polymers by FTIR spectroscopy," Journal of Applied Polymer Science 71(12), 19691975. DOI: 10.1002(SICI)1097-4628(19990321)71:12

Pandey, K. K., and Pitman, A. J. (2003). "FTIR studies of the changes in wood chemistry following decay by brown-rot and white-rot fungi," International Biodeterioration \& Biodegradation 52(3), 151-160. DOI: 10.1016/S0964-8305(03)00052-0

Phinichka, N., and Kaenthong, S. (2018). "Regenerated cellulose from high alpha cellulose pulp of steam-exploded sugarcane bagasse," Journal of Material Research and Technology 7(1), 55-65. DOI: 10.1016/j.jmrt.2017.04.003

Poletto, M., Zattera, A. J., and Santana, R. M. C. (2012). "Thermal decomposition of wood: Kinetics and degradation mechanisms," Bioresource Technology 126, 7-12.

Poletto, M., Ornaghi, Jr., H. L., and Zattera, A. J. (2014). "Native cellulose: Structure, characterization and thermal properties," Materials 7(9), 6105-6119. DOI: 10.3390/ma7096105

Rowell, R. M. (1983). "The chemistry of solid wood," Forest Products Abstracts 6(12), 363-382. DOI: 10.1021/ba-1984-0207

Runkel, R. O. H, and Wilke, K. D. (1951). "Zur Kenntnis des thermoplastischen Verhaltens von Holz," Holz als Roh-und Werkstoff 9(2), 260-270.

Satyanarayana, K. G., Guimaraes, J. L., and Wypych, F. (2007). "Studies on lignocellulosic fibers of Brazil. Part I: Source, production, morphology, properties and applications," Compos. Part A 38,1694-1709. DOI:

10.1016/j.compositesa.2007.02.006

Schwanninger, M., Rodriguez, J. C., Pereira, H., and Hinterstoisser, B. (2004). "Effects of short-time vibratory ball milling on the shape of FTIR spectra of wood and cellulose," Vibrational Spectroscopy 36(1), 23-40. DOI:

10.1016/j. vibspec2004.02.003

Stark, N. M., Umesh, A., and Yelle, D. J. (2015). "Techniques for characterizing lignin," in: Lignin in Polymer Composites, Elsevier, Madison, WI, USA, pp. 49-66. DOI: 10.1016/B978-0-323-35565-0.00004-7

TAPPI T203 cm-09 (2009). “Alpha-, beta- and gamma-cellulose in pulp,” TAPPI Press, Atlanta, GA, USA.

TAPPI T204 cm-07 (2007). "Solvent extractives of wood and pulp: Combustion at 5254 ${ }^{\circ} \mathrm{C}$," TAPPI Press, Atlanta, GA, USA.

TAPPI T211 om-12 (2012). “Ash in wood, pulp and paper," TAPPI Press, Atlanta, GA, USA.

TAPPI T257 cm-85 (2012). "Sampling and preparing wood for analysis," TAPPI Press, Atlanta, GA, USA.

TAPPI T258 om-02 (2006). "Basic density and moisture in pulpwood," TAPPI Press, Atlanta, GA, USA.

TAPPI T258 om-94 (1994). "Basic density and moisture content of pulpwood," TAPPI Press, Atlanta, GA, USA. 
Tarasov, A. E, Rodin, M. D., and Romanova, L. B. (2019). "Determining functional group locations in $\beta$-cyclodextrin nitrates," Journal of Applied Spectroscopy 86(2), 283-288. DOI: 10.1007/s1081-019-00813-5

Traore', M., Kaal1, J., and Cortizas, A. M. (2018). "Differentiation between pine woods according to species and growing location using FTIR-ATR," Wood Science and Technology 52(2), 487-504. DOI: 10.1007/s00226-017-0967-9

Tserki, V., Matzinos, P., Kokkou, S., and Panayiotou, C. (2005). "Novel biodegradable composites based on treated lignocellulosic waste flour as filler. Part I. Surface chemical modification and characterization of waste flour," Composites Part A 36, 965-974. DOI: 10.1016/j.compositesa.2004.11.010

Tutuş, A., Kurt, R., Alma, M. H., and Meriç, H. (2010). "Chemical analysis of scotch pine wood and its thermal properties, III. National Karadeniz Forestry Congress," Artvin, Turkey, pp. 1845-1851.

Wang, L. L and Wu, F. (2016). "Chemical analysis of densification, drying and heat treatment of Scots pine (Pinus sylvestris L.) through a hot-pressing process," BioResources 11(2), 3856-3874. DOI: 10.15376/biores. 11.2.3856-3874.

Wise, L. E., and John, E. C. (1952). Wood Chemistry, Volume 2, Reinhold Publishing Co., New York, NY, USA.

Yilgor, N. (2005). "Effects of some pretreatments on standard delignification, Spruce Symposium,” Karadeniz Technical University, Trabzon, Turkey, V (II), pp. 911-920.

Article submitted: September 24, 2019; Peer review completed: December 14, 2019; Revised version received: March 9, 2020; Accepted: March 10, 2020; Published: March 31, 2020.

DOI: $10.15376 /$ biores. 15.2.3604-3620 